\title{
Practice of Modern Methods of Family Planning in Two Urban Slums of Karachi and Effect of Counselling
}

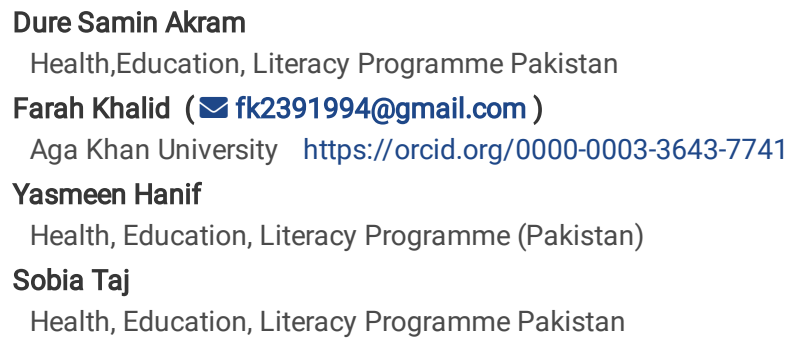

\section{Research}

Keywords: Family Planning, Slum areas, NGO, Family planning users, Condoms, Pills, IUCDs, Injections, Sterilization, Child-bearing Age, Karachi Posted Date: November 20th, 2020

DOI: https://doi.org/10.21203/rs.3.rs-111188/v1

License: (-) (1) This work is licensed under a Creative Commons Attribution 4.0 International License. Read Full License 


\section{Abstract}

\section{BACKGROUND}

The means and services used for prevention of pregnancies is referred as Family Planning (FP) (1). The successful implementation of Family Planning has remained a difficult task in Pakistan because of socio-cultural beliefs, lack of information or misinformation and lack of access to contraceptive services. Cultural taboos and social bonds related to women are major factors in the low uptake of FP services (2).

\section{METHODOLOG}

This study is the analysis of retrospective secondary data from an NGO, HELP's Family Planning clinics, to determine the trends and patterns of contraceptive methods used in two squatter settlements(Neelam Colony and KKB) in Karachi from 2010-2018.

The data originated from Mother and Child centers of HELP. Records of the monthly data collected by CHWs from their catchments areas were obtained and it was cumulated annually. Variables studied included number of women of childbearing age (CBA), number of married women of childbearing age, information about number of family planning users, number of babies born. The data also included different types of FP methods used by married couples. For analysis, the data was entered in Microsoft Excel and then exported to SPSS version 19. Mean and percentages, graphs and other graphics for all the variables were calculated and created through SPSS 19 and Excel.

\section{RESULTS}

The Mean number of FP users were 43\% in Neelum Colony and 48\% at KKB. Similar data was reported in PDHS 2017-18 that $34 \%$ of married women in Pakistan were opting for methods of family planning (3). Use of Condoms was the most commonly used method of family planning in Neelum Colony and in KKB, recorded as being $36 \%$, and $41 \%$ users respectively. The FP2020 reports that there are $34 \%$ condom users in Pakistan (4). Our study also found that that that the increase in use of FP was influenced by increased reminders and nudging techniques during counselling by $\mathrm{CHWs.}$

\section{CONCLUSIONS}

To progressively increase the practice of couples using modern FP methods, it is crucial that repeated messages giving correct scientific information regarding FP methods be given frequently. Acceptance of using FP has to be developed primarily in the male counterpart and therefore, male social mobilisers should form part of a team.

\section{Plain English Summary}

The methods and services used for the prevention of pregnancies are called Family Planning. In this study, the authors collected eight years of Family Planning trends in two urban slums of Karachi. The data collection was focused on the number of family planning users, common methods of family planning, and counseling sessions held by CHWs.

Through analysis of the data, it was found that there were $40 \%$ to $50 \%$ FP users in both the urban slums. The condom was the popular choice for family planning, whereas IUCD was the least opted method. It was also seen that during the year when the maximum number of counseling sessions was held, the trend in the use of FP methods was also increasing.

In relation to this, it can be concluded that the provision of scientific information regarding Family Planning can help to increase the use. CHWs can play a vital role in disseminating the anxiety and myths associated with FP. Empowerment of CHWs through ability and accessibility can be a good initiative. It is also emphasized that male counterparts should be targeted to increase the acceptance of FP methods.

\section{Introduction}

The means and services used for prevention of pregnancies is referred as Family Planning (FP) (1). This method helps a couple or individuals to take informed decisions regarding the number of children they plan to have, when to start having children, to give space between the birth of their children by means of contraception or complete their family by sterilization $(5,6)$. Family Planning is of significant importance as it gives a couple the power to make decisions according to their preference of giving birth whenever they feel ready. It also empowers women to care for their own health (7). Contraceptive methods are also important for improved reproductive health due to its central role in preventing the transmission of Human Immunodeficiency viruses (HIV) and other sexually transmitted diseases (STDs) $(8,9)$. Maternal and infant mortality rates are reduced by increasing use of contraception and optimum birth spacing. It curtails the rate of population growth which in turn benefits the economy and environment of the country $(10,11)$.

A report published in 2018 by WHO states that globally, 222 million women wish to stop or delay the process of childbearing but unfortunately, they are not using any contraceptive methods. These methods have proven to be effective in developing countries around the world as 55 million unplanned births, 25 million miscarriages, and 138 million abortions have been averted (11). Subsequently, Pakistan's FP 2020 Report (2017-18) informs that 36 million unplanned births, 1 million abortions and 3500 maternal deaths have been prevented with the use of contraceptive methods (4). The successful implementation of Family Planning has remained a difficult task in Pakistan because of socio-cultural beliefs, lack of information or misinformation and lack of access to contraceptive services. Cultural taboos and social bonds related to women are major factors in the low uptake of FP services (2). 
Pakistan's FP 2020 Report of 2018 states that there are 3 million users of contraceptives in Pakistan while the married contraceptive prevalence rate (mCPR) is $20.8 \%$. There are almost $29.3 \%$ women who still have unmet needs of contraception (4). Pakistan plans to achieve $55 \%$ CPR while Sindh focuses on reaching the $45 \%$ mark from $30 \%$ by the end of the year of 2020 (12). The report also shows that in Pakistan, $33.6 \%$ of males are using condoms as a method of contraception while only $1.1 \%$ opt for male sterilization. Contrastingly, $33.2 \%$ of Pakistani women are sterilized, $10.7 \%$ use injections, $8.8 \%$ use Intra-Uterine Device and 6.1\% use Pills. Lactational Amenorrhea is another method used by $5.7 \%$ of women while $0.8 \%$ use other modern methods (12). Thus FP rates need to be improved by focused efforts throughout the country.

Health, Education, Literacy Programme (HELP) is a Non-Governmental Organization (NGO). It started its Family Planning services, including counselling, in early nineties in the urban slums of Karachi. This study is the analysis of retrospective secondary data from HELP's Family Planning clinics, to determine the trends and patterns of contraceptive methods used in two such areas, Khuda ki Basti (KKB) and Neelum Colony, Karachi from $2010-2018$.

\section{Methodology}

\section{Study Design and Setting:}

We collected data from HELP's archives. The data originated from Mother and Child centers present at KKB and Neelum Colony. These health facilities provide services of family planning, antenatal, postnatal care, perinatal services, immunization and nutrition related services for women and children. It also caters to the unmet need of family planning services at the doorsteps of the community through Community Health Workers (CHWs).

\section{Data collection and Statistical Analysis:}

Records of the monthly data collected by CHWs from their catchments areas were obtained. Data was cumulated annually. Thus annual data of 2010 - 2018 was included for analysis. Variables studied included number of women of childbearing age (CBA), number of married women of childbearing age, information about number of family planning users, number of babies born. The data also included different types of FP methods used by married couples including pills, condoms, injections, intra-uterine contraceptive devices (IUCD), and tubal ligations other natural methods.

For analysis, the data was entered in Microsoft Excel and then exported to SPSS version 19. Mean and percentages, graphs and other graphics for all the variables were calculated and created through SPSS 19.

\section{Results And Discussions Family Planning Variables in Neelum Colony and KKB}

The mean number of CBAs from 2010-2018 in Neelum Colony was 2520 and 4225 at KKB. The mean value of married CBAs in Neelum Colony was 1,851 while 2896 was the mean number of married CBAs recorded at KKB. Mean number of babies born from 2010 to 2018 were 11 per month in Neelum Colony and while 26 children per month were born in KKB.

The Mean number of FP users were $43 \%$ in Neelum Colony and $48 \%$ at KKB. Similar data was reported in PDHS $2017-18$ that $34 \%$ of married women in Pakistan were opting for methods of family planning. It was also reported that $34 \%$ women of urban areas were more likely to use contraceptive methods when compared to $29 \%$ women of rural area. The statistics of Sindh report that $28 \%$ of urban married women while $20 \%$ of married women from rural area were using modern contraceptive methods(3). The CHW's of HELP also provided services of counselling to the community which included topics such as maternal and child nutrition, family planning and its methods and antenatal care. Subsequently, the mean Counselling sessions held in each area, were 542 from 2010-2018 in Neelum Colony and 1477 at KKB per month.

\section{Methods opted for Family Planning}

Use of Condoms was the most commonly used method of family planning in Neelum Colony and in KKB, recorded as being $36 \%$, and $41 \%$ users respectively. The FP2020 reports that there are 34\% condom users in Pakistan (4). In Sindh $11.4 \%$ of urban FP users opted for Condoms while only $1.5 \%$ of rural FP users opted for condoms. Tubal ligation (TL) was the second most frequent method opted by females at both the sites with mean number of users recorded to be $26 \%$ in Neelum Colony and $29 \%$ at KKB. $33 \%$ of Pakistani women opted for sterilization (4). Tubal ligation ( $9 \%$ ) was the second most common method of FP and in Sindh 10\% were urban women and $9 \%$ were rural women opted for TL (3).

Injections for birth control was the third major method of Family Planning used by the residents of Neelum Colony (17\%) and KKB (11\%). In Pakistan 11\% of the women opted for injections as contraceptive method (4). PDHS reports $2.0 \%$ women of urban areas of Sindh were using injections as a method of FP while $3.4 \%$ of women from rural areas were using injectable. The number of females using birth control pills in Neelam Colony was $11 \%$, whereas in KKB, the mean number of pill users $8 \%$. However, according to the PDHS Survey $2017-2018,1.9 \%$ of women of Urban Sindh and $2.9 \%$ of rural women were utilizing pills. Lastly, IUCD was the least common method opted by married CBAs of both study sites with mean number of users being $8.3 \%$ in Neelum and $6.7 \%$ recorded at KKB. Based on the PDHS Survey, $1.9 \%$ of users were reported in urban Sindh and $1.2 \%$ in rural Sindh (3).

When the data was reviewed for trends, it was documented that the percentage of 1033 (52\%) FP users was maximum in Neelum Colony in 2015. In the same year a maximum number of counselling sessions were also held (906). When compared with KKB, the counselling session frequency remained steady over the years and so did the frequency of FP practiced by couples. 
It is conceivable that the increase in use of FP in Neelam Colony in a particular year was influenced by increased reminders and nudging techniques during counselling by CHWs. This can be further assessed in chart 1 .

A study conducted in rural Tanzania reported that education provided by community health workers regarding maternal healthcare is feasible and effective (13). In a cluster randomized trial conducted amongst Malawi couples, regarding the uptake of Family Planning methods, results showed that community health workers counselling initiative was successful in making couples use modern methods of FP. It also led to an increase in the involvement of males and a trend towards increased use of condoms (14).

\section{Conclusion And Recommendations}

To progressively increase the practice of couples using modern FP methods, it is crucial that repeated messages giving correct scientific information regarding FP methods be given frequently. Services should always include easy accessibility and the ability of CHWs to be able to respond to queries and allay any anxiety related to FP use. Acceptance of using FP has to be advocated primarily in the male counterpart and therefore, male social mobilisers should form part of a team to bring about acceptance and demand towards the use of appropriate methods of birth spacing and FP.

\section{Abbreviations}

FP: Family Planning

NGO: Non-Governmental Organization

HELP: Health, Education, Literacy Programme

KKB: Khuda ki Basti

CHW: Community Health Workers

HIV: Human Immunodeficiency Viruses

STD: Sexually Transmitted Diseases

IUCD: Intrauterine Device

TL: Tubal Ligation

PDHS: Pakistan Demographic and Health Survey

HCW: Health care worker

\section{Declarations}

- Ethics approval and consent to participate: Ethical Approval was taken from HELP.

- Consent for publication: Consent for Publication is taken from HELP.

- Availability of data and materials: Not applicable

- Competing interests: Authors have no competing interests.

- Funding: No funding was received for the manuscript

- Authors' contributions: Data was provided by Dr. DS Akram's NGO. She also supervised the manuscript writing and data analysis procedure. She provided her writing and editing services. The data analysis and manuscript writing was done by Farah Khalid. Dr Sobia Taj did data analysis and reporting of results. Dr Yasmeen Hanif helped witb the editing of the manuscript. She also helped in writing the discussion.

- Acknowledgements: The authors would like to acknowledge all the CHWs who work for HELP.

- Authors' information (optional):

- DR DURE SAMIN AKRAM, Professor of Pediatrics,(pride of performance); MBBS, M.D, MPH; Diplomate American Boards in Pediatrics; Hon. Chairperson, Health, Education \& Literacy Programme (Pakistan).

dsakram@gmail.com

- Farah Khalid: Aga Khan University Hospital, Karachi, Pakistan ORCID: 0000-0003-3643-7741 fk2391994@gmail.com

- Dr. Yasmeen Hanif. Health Education, Literacy Programme (HELP), yasmeen.hanif@helpngo.org.pk

- Dr. Sobia Taj: Health Education, Literacy Programme (HELP), Karachi, Pakistan sobiataj@hotmail.com

\section{References}


1. Tolefac PN, Nana TN, Yeika EV, Awungafac NS, Ntsama Y, Njotang PN. Trends and patterns of family planning methods used among women attending family planning clinic in a rural setting in sub-Sahara Africa: the case of Mbalmayo District Hospital, Cameroon. BMC research notes. 2018;11(1):541.

2. PBS. CONTRACEPTIVE PERFORMANCE REPORT 2015-2016: Governement of Pakistan; 2017 [Available from:

http://www.pbs.gov.pk/sites/default/files/social_statistics/contraceptive_performance_reports/Final\%20Report\%20April\%2C\%202017\%28Final\%29.pdf.

3. ICF NIoPSNPa. Pakistan Demographic and Health Survey 2017-18. Islamabad, Pakistan, and Rockville, Maryland, USA: National Institute of Population Studies and Macro International Inc; 2019.

4. FP2020. Annual Progress Reports 2017-2018, : FP2020; 2018 [Available from: http://www.familyplanning2020.org/sites/default/files/Pakistan\%202018\%20Cl\%20Handout.pdf.

5. Cleland J, Bernstein S, Ezeh A, Faundes A, Glasier A, Innis J. Family planning: the unfinished agenda. The Lancet. 2006;368(9549):1810-27.

6. Çalikoğlu EO, Yerli EB, Kavuncuoğlu D, Yılmaz S, Koşan Z, Aras A. Use of Family Planning Methods and Influencing Factors Among Women in Erzurum. Medical science monitor: international medical journal of experimental and clinical research. 2018;24:5027.

7. Okunade KS, Daramola E, Ajepe A, Sekumade A. A 3-year review of the pattern of contraceptive use among women attending the family planning clinic of a University Teaching Hospital in Lagos, Nigeria. African Journal of Medical and Health Sciences. 2016;15(2):69.

8. Jahan U, Verma K, Gupta S, Gupta R, Mahour S, Kirti N, et al. Awareness, attitude and practice of family planning methods in a tertiary care hospital, Uttar Pradesh, India. Int J Reprod Contracept Obstet Gynecol. 2017;6(2):500-6.

9. Wani RT, Rashid I, Nabi SS, Dar H. Knowledge, attitude, and practice of family planning services among healthcare workers in Kashmir-A cross-sectional study. Journal of family medicine and primary care. 2019;8(4):1319.

10. Yangsi TT, Florent FY, Ngole ME, Nelson F. Modern contraceptive choice among patients seen at the "Cameroon National Planning Association for Family Welfare" clinic Yaoundé. Clinical Medicine Insights: Reproductive Health. 2017;11:1179558117713016.

11. WHO. Family planning/Contraception: WHO; 2018 [Available from: https://www.who.int/en/news-room/fact-sheets/detail/family-planningcontraception.

12. IPPF. Spotlight on Family Planning: Tracking Progress on the FP2020 Pledges 2015 [Available from: https://www.ippf.org/sites/default/files/spotlight_pakistan_v201_web.pdf.

13. August F, Pembe AB, Mpembeni R, Axemo P, Darj E. Community health workers can improve male involvement in maternal health: evidence from rural Tanzania. Global health action. 2016;9(1):30064.

14. Lemani C, Tang JH, Kopp D, Phiri B, Kumvula C, Chikosi L, et al. Contraceptive uptake after training community health workers in couples counseling: A cluster randomized trial. PloS one. 2017;12(4).

\section{Tables}

\section{Table 1: Details of CBAs and use of FP}

\begin{tabular}{|c|c|c|c|c|c|c|c|c|c|c|c|}
\hline & \multicolumn{2}{|c|}{ CBA 15- 49} & \multicolumn{2}{|c|}{ Married CBA } & \multicolumn{2}{|c|}{ Babies Born/month } & \multicolumn{3}{|c|}{ FP USERS } & \multicolumn{2}{|c|}{ Counseling Sessions } \\
\hline & Neelum & KKB & Neelum & KKB & Neelum & KKB & & Neelur & KKB & Neelum & KKB \\
\hline Mean & 2520.11 & 4225 & 1851.3333 & 2896 & 11 & 26 & 810 & $43 \%$ & $141648 \%$ & 541.7778 & 1477 \\
\hline 2010 & 2440 & 4352 & 1830. & 2906.33 & 14 & 29 & 663. & $036 \%$ & $1527.6752 \%$ & 481.00 & 1376.83 \\
\hline 2011 & 2562 & 4608 & 1870.00 & 2980.50 & 14 & 28 & 803. & $0042 \%$ & $1365.8345 \%$ & 563.00 & 1614.50 \\
\hline 2012 & 2438 & 4426 & 1826.00 & 2938.33 & 9 & 25 & 803. & $043 \%$ & $1717.8358 \%$ & 601.00 & 1223.83 \\
\hline 2013 & 2125 & 4234 & 1576.00 & 2862.42 & 11 & 25 & 667. & $0042 \%$ & $1573.7554 \%$ & 476.00 & 1297.00 \\
\hline 2014 & 2773 & 4199 & 1830.00 & 2882.17 & 12 & 23 & 946. & $5051 \%$ & $1331.0846 \%$ & 547.00 & 1489.42 \\
\hline 2015 & 2840 & 3841 & 1969.00 & 2726.67 & 13 & 22 & 1033 & $.0052 \%$ & $1385.6750 \%$ & 906.00 & 1341.00 \\
\hline 2016 & 2672 & 4009 & 2197.00 & 2869.33 & 13 & 28 & 869. & $0039 \%$ & $1391.1748 \%$ & 499.00 & 1450.50 \\
\hline 2017 & 2456 & 4634 & 1987.00 & 3335.17 & 7 & 28 & 685. & $034 \%$ & $1355.5040 \%$ & 392.00 & 1974.08 \\
\hline 2018 & 2375 & 3727 & 1748.00 & 2562.08 & 10 & 24 & 663. & $0038 \%$ & $1094.9242 \%$ & 411.00 & 1523.00 \\
\hline
\end{tabular}

Table 2: Number of FP users and methods of FP 


\begin{tabular}{|c|c|c|c|c|c|c|c|c|c|c|c|c|}
\hline & \multicolumn{2}{|c|}{ FP_USERS. } & \multicolumn{2}{|c|}{ Condoms } & \multicolumn{2}{|l|}{ Pills } & \multicolumn{2}{|l|}{ Injection } & \multirow{2}{*}{$\begin{array}{l}\text { IUCD } \\
\text { Neelum }\end{array}$} & \multicolumn{2}{|c|}{ Tubal Ligation } & \multirow[b]{2}{*}{ KKB } \\
\hline & Neelum & KKB & Neelum & KKB & Neelum & KKB & Neelum & KKB & & KKB & Neelum & \\
\hline Mean & $\begin{array}{l}810 \\
43 \%\end{array}$ & $\begin{array}{l}1416 \\
48 \%\end{array}$ & $\begin{array}{l}292 \\
36 \%\end{array}$ & $58841 \%$ & $\begin{array}{l}96 \\
11.85 \%\end{array}$ & $\begin{array}{l}122 \\
8.61 \%\end{array}$ & $\begin{array}{l}142 \\
17.5 \%\end{array}$ & $\begin{array}{l}168 \\
11.8 \%\end{array}$ & $\begin{array}{l}68 \\
8.3 \%\end{array}$ & $\begin{array}{l}96 \\
6.7 \%\end{array}$ & $\begin{array}{l}213 \\
26.2 \%\end{array}$ & $\begin{array}{l}421 \\
29 \%\end{array}$ \\
\hline 2010 & $\begin{array}{l}663.00 \\
36 \%\end{array}$ & $\begin{array}{l}1527.67 \\
52 \%\end{array}$ & $\begin{array}{l}211 \\
31 \%\end{array}$ & $\begin{array}{l}465 \\
30.4 \%\end{array}$ & $\begin{array}{l}139 \\
20 \%\end{array}$ & $\begin{array}{l}197 \\
12.90 \%\end{array}$ & $\begin{array}{l}168 \\
25 \%\end{array}$ & $\begin{array}{l}223 \\
14.6 \%\end{array}$ & $\begin{array}{l}69 \\
10.4 \%\end{array}$ & $\begin{array}{l}122 \\
7.9 \%\end{array}$ & $\begin{array}{l}230 \\
34.6 \%\end{array}$ & $\begin{array}{l}521 \\
34.11 \%\end{array}$ \\
\hline 2011 & $\begin{array}{l}803.00 \\
42 \%\end{array}$ & $\begin{array}{l}1365.83 \\
45 \%\end{array}$ & $\begin{array}{l}244 \\
30.38 \%\end{array}$ & $48635 \%$ & $\begin{array}{l}122 \\
15.1 \%\end{array}$ & $\begin{array}{l}147 \\
10.7 \%\end{array}$ & $\begin{array}{l}155 \\
19.30 \%\end{array}$ & $\begin{array}{l}172 \\
12.6 \%\end{array}$ & $\begin{array}{l}55 \\
6.84 \%\end{array}$ & $\begin{array}{l}110 \\
8.0 \%\end{array}$ & $\begin{array}{l}227 \\
28.26 \%\end{array}$ & $\begin{array}{l}450 \\
32.9 \%\end{array}$ \\
\hline 2012 & $\begin{array}{l}803.00 \\
43 \%\end{array}$ & $\begin{array}{l}1717.83 \\
58 \%\end{array}$ & $\begin{array}{l}285 \\
35.49 \%\end{array}$ & $\begin{array}{l}640 \\
37.25 \%\end{array}$ & $\begin{array}{l}104 \\
12.9 \%\end{array}$ & $\begin{array}{l}162 \\
9.4 \%\end{array}$ & $\begin{array}{l}157 \\
19.55 \%\end{array}$ & $\begin{array}{l}199 \\
46.35 \%\end{array}$ & $\begin{array}{l}48 \\
5.9 \%\end{array}$ & $\begin{array}{l}106 \\
6.17 \%\end{array}$ & $\begin{array}{l}209 \\
26 \%\end{array}$ & $\begin{array}{l}612 \\
35.6 \%\end{array}$ \\
\hline 2013 & $\begin{array}{l}667.00 \\
42 \%\end{array}$ & $\begin{array}{l}1573.75 \\
54 \%\end{array}$ & $\begin{array}{l}254 \\
38 \%\end{array}$ & $\begin{array}{l}561 \\
35.6 \%\end{array}$ & $\begin{array}{l}70 \\
10 \%\end{array}$ & $\begin{array}{l}142 \\
9.0 \%\end{array}$ & $\begin{array}{l}133 \\
19.9 \%\end{array}$ & $\begin{array}{l}230 \\
14.6 \%\end{array}$ & $\begin{array}{l}50 \\
7.4 \%\end{array}$ & $\begin{array}{l}105 \\
6.67 \%\end{array}$ & $\begin{array}{l}168 \\
25 \%\end{array}$ & $\begin{array}{l}537 \\
34.1 \%\end{array}$ \\
\hline 2014 & $\begin{array}{l}946.00 \\
51 \%\end{array}$ & $\begin{array}{l}1331.08 \\
46 \%\end{array}$ & $\begin{array}{l}406 \\
42 \%\end{array}$ & $64048 \%$ & $\begin{array}{l}99 \\
10.4 \%\end{array}$ & $\begin{array}{l}87 \\
6.55 \%\end{array}$ & $\begin{array}{l}166 \\
17 \%\end{array}$ & $\begin{array}{l}151 \\
11.3 \%\end{array}$ & $\begin{array}{l}62 \\
6.5 \%\end{array}$ & $\begin{array}{l}79 \\
5.9 \%\end{array}$ & $\begin{array}{l}214 \\
22 \%\end{array}$ & $\begin{array}{l}366 \\
27.4 \%\end{array}$ \\
\hline 2015 & $\begin{array}{l}1033 \\
52 \%\end{array}$ & $\begin{array}{l}1385.67 \\
50 \%\end{array}$ & $\begin{array}{l}402 \\
39.3 \%\end{array}$ & $72152 \%$ & $\begin{array}{l}101 \\
9.7 \%\end{array}$ & $\begin{array}{l}87 \\
6.2 \%\end{array}$ & $\begin{array}{l}198 \\
19 \%\end{array}$ & $\begin{array}{l}147 \\
10.6 \%\end{array}$ & $\begin{array}{l}80 \\
7.7 \%\end{array}$ & $\begin{array}{l}93 \\
6.7 \%\end{array}$ & $\begin{array}{l}255 \\
24 \%\end{array}$ & $\begin{array}{l}330 \\
23.8 \%\end{array}$ \\
\hline 2016 & $\begin{array}{l}869.00 \\
39 \%\end{array}$ & $\begin{array}{l}1391.17 \\
48 \%\end{array}$ & $\begin{array}{l}317 \\
36 \%\end{array}$ & $\begin{array}{l}715 \\
51.4 \%\end{array}$ & $\begin{array}{l}91 \\
6.5 \%\end{array}$ & $846.0 \%$ & $\begin{array}{l}138 \\
15.8 \%\end{array}$ & $\begin{array}{l}137 \\
9.8 \%\end{array}$ & $\begin{array}{l}76 \\
8.7 \%\end{array}$ & $\begin{array}{l}90 \\
6.4 \%\end{array}$ & $\begin{array}{l}248 \\
28 \%\end{array}$ & $\begin{array}{l}356 \\
26.9 \%\end{array}$ \\
\hline 2017 & $\begin{array}{l}685.00 \\
34 \%\end{array}$ & $\begin{array}{l}1355.50 \\
40 \%\end{array}$ & $\begin{array}{l}247 \\
36 \%\end{array}$ & $\begin{array}{l}632 \\
46.6 \%\end{array}$ & $\begin{array}{l}76 \\
11 \%\end{array}$ & $\begin{array}{l}103 \\
7.6 \%\end{array}$ & $\begin{array}{l}91 \\
13.2 \%\end{array}$ & $\begin{array}{l}140 \\
10.33 \%\end{array}$ & $\begin{array}{l}89 \\
12.9 \%\end{array}$ & $\begin{array}{l}83 \\
6.1 \%\end{array}$ & $\begin{array}{l}182 \\
26.5 \%\end{array}$ & $\begin{array}{l}331 \\
24.4 \%\end{array}$ \\
\hline 2018 & $\begin{array}{l}663.00 \\
38 \%\end{array}$ & $\begin{array}{l}1094.92 \\
42 \%\end{array}$ & $\begin{array}{l}262 \\
39 \%\end{array}$ & $\begin{array}{l}434 \\
42.4 \%\end{array}$ & $\begin{array}{l}62 \\
9.3 \%\end{array}$ & $898.1 \%$ & $7311 \%$ & $\begin{array}{l}116 \\
10.6 \%\end{array}$ & $\begin{array}{l}85 \\
12.8 \%\end{array}$ & $\begin{array}{l}74 \\
6.7 \%\end{array}$ & $\begin{array}{l}180 \\
27.1 \%\end{array}$ & $\begin{array}{l}288 \\
26.3 \%\end{array}$ \\
\hline
\end{tabular}

Figures

\section{Family Planning Users and Counselling Sessions}

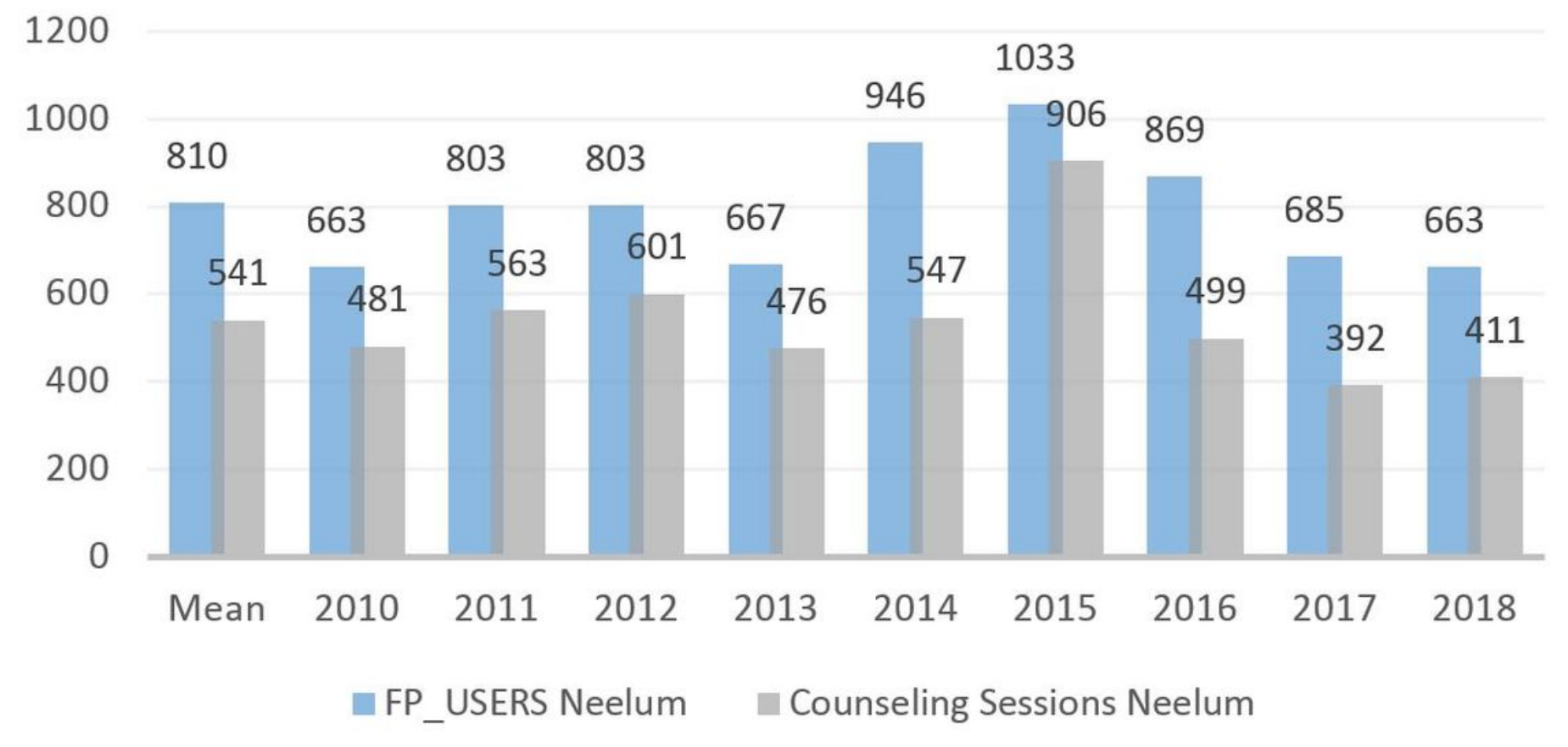




\section{Family Planning Users and Counselling Sessions}

2500

2000

1500

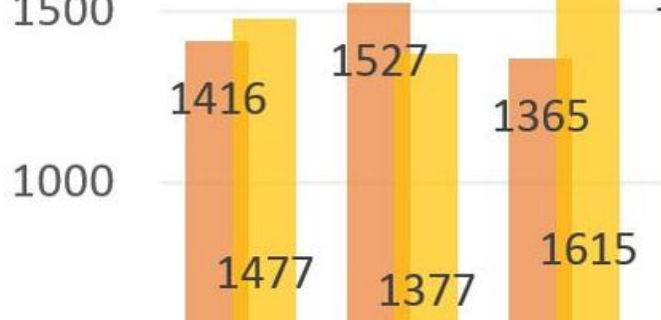

500

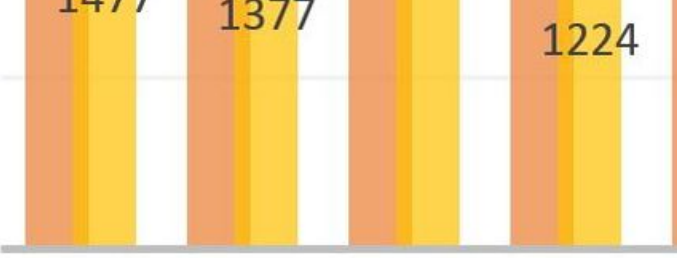

1573

1331

13851391

1355

0

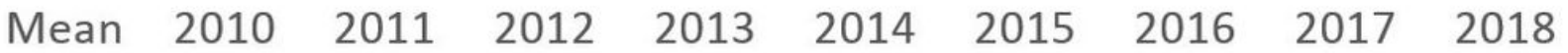

$$
\begin{aligned}
& \text { EP_USERS KKB } \quad \text { Counseling Sessions KKB }
\end{aligned}
$$

\section{Figure 2}

Trends of Family Planning users and Counselling sessions in KKB 